\title{
ASPECTS OF CLONAL MICROPROPAGATION AND CONSERVATION OF PLANTS IN VITRO
}

\author{
Victoria O. Samarskaya \\ Volgograd State University, Volgograd, Russian Federation \\ Elena V. Malaeva \\ Volgograd Regional Botanical Garden, Volgograd, Russian Federation; \\ Volgograd State Social and Pedagogical University, Volgograd, Russian Federation \\ Margarita V. Postnova \\ Volgograd State University, Volgograd, Russian Federation
}

\begin{abstract}
Despite more than a century of research on effective biotechnological methods to reproduce various plant species, microclonal reproduction continues to be an important tool for large-scale production. The clonal seedlings of important species maintain genetic fidelity and do not contain pests. In some cases, microclonal propagation is the only method that contributes to the maintenance and economic value of specific agricultural plant species. Microclonal reproduction as a method has solved many phytosanitary problems and has allowed both expansion and access to high-quality plants for producers from different countries and economic conditions, thus effectively contributing to the expansion of agriculture now and in the foreseeable future. Currently, this method is widely used in the creation of planting material for crops for agriculture and cultivation of crops of industrial floriculture, fruit, berry crops and woody plants. Thanks to this method, it is possible to create in vitro banks of rare and valuable plant genotypes. Modern technologies of clonal micro-multiplication are at the stage of industrial flow, which quickly responds to market demands. The analysis of domestic and foreign sources of scientific research on microclonal plant propagation has shown that, at the present time, the cost of its use is quite high and requires the presence of laboratories with appropriate equipment and highly qualified staff. Modification and adaptation of the method of microclonal reproduction of plants contributes to the implementation of the morphogenetic potential, determines the specific features of the source material, the type of explant, its physiological state, the composition of nutrient media, and cultivation conditions. At the same time, the cultivation of healthy 2 plants will significantly increase the yield of valuable agricultural products and high adaptive properties of healthy ․ plants that allow them to be cultivated with less chemicals, which will significantly increase their nutritional value $\oplus$ and give a greater opportunity to obtain organic products with high-quality characteristics.
\end{abstract}

Key words: biotechnology, clonal propagation, organogenesis, in vitro culture, rooting, isolated explants.

УДК 606:631.53

ББК 41.318

\section{АСПЕКТЫ КЛОНАЛЬНОГО МИКРОРАЗМНОЖЕНИЯ И СОХРАНЕНИЯ РАСТЕНИЙ IN VITRO}

\author{
Виктория Олеговна Самарская \\ Волгоградский государственный университет, г. Волгоград, Российская Федерация \\ Елена Викторовна Малаева \\ Волгоградский региональный ботанический сад, г. Волгоград, Российская Федерация; \\ Волгоградский государственный социально-педагогический университет, \\ г. Волгоград, Российская Федерация
}




\title{
Маргарита Викторовна Постнова
}

\author{
Волгоградский государственный университет, г. Волгоград, Российская Федерация
}

\begin{abstract}
Аннотация. Несмотря на более чем вековые исследования эффективных биотехнологических методов размножения различных видов растений, микроклональное размножение продолжает оставаться важным инструментом для крупномасштабного производства клональных саженцев важных видов, которые сохраняют генетическую верность и не содержат вредителей. В некоторых случаях микроклональное размножение является единственным методом, который способствует поддержанию и повышает экономическую ценность конкретных сельскохозяйственных видов растений. Микроклональное размножение как метод решило многие фитосанитарные проблемы и позволило как расширить, так и получить доступ к высококачественным растениям для производителей из разных стран и экономических условий, тем самым эффективно способствуя расширению сельского хозяйства в настоящее время и в обозримом будущем. В настоящее время, этот метод широко используется при создании посадочного материала культур для сельского хозяйства и разведения культур промышленного цветоводства, плодовых, ягодных культур и древесных растений. Благодаря применению данного метода, появилась возможность создания банков in vitro редких и ценных генотипов растений. Современные технологии клонального микроразмножения находятся на стадии промышленного потока, который быстро реагирует на запросы рынка. Анализ отечественных и зарубежных источников научных исследований по микроклональному размножению растений показал что, в настоящее время себестоимость его применения достаточно высока и требует наличия в лабораторий с соответствующим оборудованием и высококвалифицированным штатом сотрудников. Модификация и адаптация метода микроклонального размножения растений способствует реализации морфогенетического потенциала, определяет видовые особенности исходного материала, тип экспланта, его физиологическое состояние, состав питательных сред и условия культивирования. При этом, разведение оздоровленных растений позволит значительно увеличить выход ценной сельскохозяйственной продукции и высокие адаптационные свойства оздоровленных растений позволяющие культивировать их с меньшими затратами химикатов, что значительно увеличит их пищевую ценность и даст большую возможность получать продукты органического производства с высококачественными характеристиками.
\end{abstract}

Ключевые слова: биотехнология, клональное размножение, органогенез, культура in vitro, укоренение, изолированные экспланты.

Введение. Благодаря современным научным достижениям в области исследования клеток и тканей прогресс пришел к созданию принципиально нового метода вегетативного размножения растений, который называется - клональное микроразмножение. В основе данного метода лежит способность клетки растения при определенных условиях реализовывать присущее ей свойство - тотипотентность. Данный метод имеет преимущество перед традиционными способами размножения, которые уже применяются в современном растениеводстве [2; 29]. Применение биотехнологических способов размножения растений позволяют получить посадочный материал, который свободен от вирусов и фитопатогенов, за небольшой период времени и в достаточном количестве. Применение данного метода позволяет незамедлительно, размножить клон растения, то есть сорт или вид, получить в нужном количестве вегетативное потомство трудно размножаемых видов, сортов и форм растений. Этот способ позволяет планировать выпуск растений к определенному времени и на долгосрочную перспективу, а так же сохранять растения в условиях in vitro, и получать трансгенные растения без риска заражения карантинными вредителями и болезнями. В настоящее время, этот метод широко используется присоздании посадочного материала культур для сельского хозяйства и разведения культур промышленного цветоводства, плодовых, ягодных культур и древесных растений $[13 ; 24 ; 28]$.

Клонирование с помощью органов, клеток, тканей и клеточных культур для многих видов растений нашло широкое коммерческое применение. Однако для некоторых видов растений - клональное размножение in vitro в настоящее время крайне затруднено.

Так, при клонировании древесных культур, особенно хвойных, существуют значительные трудности. Так, например, сосна крайне сложно вводится в культуру и размножается in vitro. Ее целесообразно размножать семенами. 
Благодаря клональному микроразмножению, появилась возможность создания банков in vitro редких и ценных генотипов растений. Во многих странах микроклональное размножение растений наиболее широкое распространение получило в XX веке. В настоящее время технологии клонального микроразмножения находятся на стадии инновационной технологии использования, которая интенсивно и в сжатые сроки реагирует на рыночный спрос. За последние 15 лет растения, размножаемые в условиях in vitro, увеличились в количественном составе на треть. Лидирующими странами в данной производственной области выступают Индия, США, Израиль, Нидерланды, Италия, Польша. относительно Соединенных Штатов Америки можно констатировать тот факт что более сотни лабораторий на этой територрии занимаются клональным микроразмножением растений. Относительно Европейских стран можно констатировать, что около 250 коммерческих лабораторий используют данный метод. Италия, например, специализируется на микроразмножении культурных плодовых растений таких как, яблони, сливы и персик. Использование клонального размножения дает возможность эффективно перейти на высокопродуктивные сорта. Например, известная компания АВТ распространяет in vitro сорта кардамона с урожайностью почти 250 кг/га при урожае обычных сортов 70 кг/ га. Правительство создало им систему мер для поддержки и развития клонального микроразмножения и облегчения экспорта продукции за рубеж.

При работе с видами растений, в том числе редкими, занесенными в Красную книгу Российской Федерации или региональный Красные книги наиболее доступным и эффективным является использование в качестве первичных эксплантов семян. Размножение растений in vitro используя в качестве эксплантов семяна, которые обладают различными типами покоя, предварительной их не обрабатыавая, позволяют не выводят семена из состояния покоя.

Современные подходы для нарушения покоя семян и повышения их всхожести в условиях культуры in vitro включают в себя такие качества как: -нарушение покровов семян;
- воздействие низких положительных температур;

- экзогенная гормональная обработка семян;

- воздействие светом;

- использование свежесобранных семян;

- использование незрелых семян и культуры незрелых зародышей;

- симбиотическое культивирование и прочее.

Клональное микроразмножение определяется как сложный многофакторный физиологический процесс, состоящий из двух принципиально разных этапов, таких как in vitro и ex vitro, базирующиеся на единой теориетической основе включающей в себя с одной стороны морфогенез и регенерацию в условиях in vitro, с другой, структурно-функциональную адаптацию регенерантов в условиях ex vitro.

Установлено, что на процесс клонального микроразмножения оказывают влияние комплекс факторов: генетические, физиологические, гормональные и физические факторы. При этом степень влияния каждого из них зависит от генотипа. Анализ факторных данных показал что необходимо их учитывать при разработке и оптимизации приемов и более полную реализацию морфогенетического потенциала эксплантов при микроразмножении растений $[10 ; 11 ; 16 ; 26]$.

Обсуждение результатов. Стандартно выделяют несколько основных этапов клонального микроразмножения. Во-первых, это введение в культуру in vitro, туда входит выбор растения донора, изоляция и стерилизация экспланта; этап микроразмножения, где ключевую роль играет подбор минеральной основы питательной среды и тип и концентрация фитогормонов; укоренение in vitro и адаптация к не стерильным условиям. На этапе введения в культуру in vitro важно получить культуру, которая будет свободна от инфекций, и добиться инициации экспланта на питательной среде. Эффективность этапа во многом определяется генотипом растения, физиологическим состоянием экспланта и его происхождением.

Так в своих исследованиях ряд авторов, для первичного материала и введения в культуру редких видов растений использовали в 
основном семена, собираемые в природных местах произрастания редких и исчезающих видов растений (виды семейства Brassicaceae, Fabaceae, Caryophyllaceae и Asteraceae; части почек возобновления с кусочком донца из луковицы (Bellevalia speciosa Woronow ex Grossh.), сегменты листьев, частей околоцветника (Iris pumila L., Iris scariosa Willd. Ex Link.) на разных стадиях развития (в фазе бутонизации или цветения). Для ряда видов (Aristolochia manshuriensis Kom., Artemisia salsoloides Willd., Parthenocissus tricuspidata (Siebold. Et Zucc.) Planch.) в качестве первичных эксплантов брали апикальные и латеральные меристемы.

Использование первичных эксплантов при клональном микроразмножении плодово ягодных культур берутся одноглазковые черенки и меристематические участки апикальных и латеральных почек, а для получения каллусных культур - листья и фрагменты стебля. Оптимальный размер экспланта от 0,1 до 2 см.

Используя в анализируемом методе работы с растениями наиболее важным является этап по использованию культуры ткани где необходимо учитывать сроки изоляции экспланта. Оптимальным сроком изоляции эксплантов большинства культур является фаза начала активного роста (апрель-май). По результатам наших исследований, выход жизнеспособных эксплантов составляет 60-83 \% [8; 12]. Литературные данные подтверждают наши сведения. Экспланты, изолированные в рекомендуемые временные рамки наименее могут быть подвергнуты различным отрицательным явлениям, которые взаимосвязанны с процессами окисления и поликонденсации фенольных соединений [4].

Относительно рекомендуемого состава питательных сред и условий культивирования на этапе микроразмножения у определенных видов и сортов растений, типов тканей необходимо подбирать индивидуальную рецептуру для каждого конкретного случая.

В настоящее время известно большое число различных по составу питательных сред, но наиболее часто применяется среда Т. Мурасиге и Ф. Скуга (Murashige and Skoog, 1962). Данная среда содержит в своем составе оптимально сбалансированный набор питатель- ных веществ. Использование другого состава питательных сред имеет от нее отличие, как правило, в соотношении аммонийного и нитратного азота - это например : среды Линсмайера и Скуга (Linsmaier, Skoog, 1965), WPM (Lloyd, McCown, 1980), QL (Quorin, Lepoivre, 1977), Грешоффа и Доя (ДВМ-1) (Gresshof, Doy, 1972), Нича (Nitsch, 1974), Хеллера (Heller, 1953), Шенка и Хильдебрандта (Schenk, Hildebrandt, 1972) [3; 7].

Собственный опытпоказывает что, для большинства культур на этапе введения в культуру in vitro желательно использовать универсальную питательную среду Мурасиге-Скуга с добавлением 0,5-1 мг/л 6-БАП, 20-40 г/л сахарозы или глюкозы и 6-8 г/л агара.

Для получения и поддержания активно пролиферирующей культуры in vitro важным является правильный выбор цитокинина. Положительные результаты были получены при использовании для микроклонального размножения различных таксономических групп растений цитокинина 6-БАП (6-benzylaminopurine) $[5 ; 14 ; 19]$. На этапах введения и микроразмножения в своей практике использовали следующие регуляторы роста: 6-бензиламинопурин (6-БАП), зеатин (Z), кинетин - 6-фурфуриламинопурин, 2-изопентиниладенин (2-іР), цитодеф (ЦФ), тидиазурон (TDZ). По результатам наших исследований, установлены оптимальные концентрации цитокининов и их сочетания с ауксинами для получения оптимальных коэффициентов размножения для редких, ценных и плодово-ягодных культур $[9 ; 18]$.

При укоренении многих культур используется половинная концентрация солей макроэлементов питательной среды на основе прописи МурасигеСкуга (Murashige, Skoog, 1962). Для укоренения древесных плодовых культур часто используют минеральную основу питательной среды WPM (Lloyd, McCown, 1980).

В качестве индукторов ризогенеза используют следующие ауксины: в-индолилуксусная кислота (ИУК), в-индолилмасляная кислота (ИМК) и б-нафтилуксусная кислота (НУК). Побеги разных культур специфично реагируют на тип ауксина и его концентрацию. Чаще всего используют концентрацию ауксинов в пределах 0,5-5,0 мг/л. 
Относительно собственного опыта, наиболее уязвимым и важным моментом при клональном микроразмножении выступает перевод растений из асептической культуры в нестерильные условия.

Растения оптимально адаптируются к условиям in vivo в первые две недели именно в этот период существенную необходимость имеет факт поддержания относительной влажности в пределах 75-80\%. Данные условия обеспечиваются за счет создания условий так называемой «влажной камеры» с режимом ежедневного кратковременного проветривания. Температурный режим должен быть не ниже $20{ }^{\circ} \mathrm{C}$ и не выше $25^{\circ} \mathrm{C}$, так как снижение температуры способствует замедлению темпа роста, а так же необходимо обеспечивать высокую освещенность помещения, где осуществляется разведение растений.

В сроки от 2-х до 3-х месяцев после адаптации растения рекомендуется высаживать в открытый грунт. В качестве собственного опыта рекомендуется использовать субстрат из смеси торфа, песка и почвы при соотношении $1: 1: 1$. При этом, выход адаптированных растений составляет 70-95\%.

В зависимости от части растения, которое культивируется, мы можем отнести их к культуре клеток (гаметические клетки, суспензия клеток и культура протопластов), культуре тканей (каллусные и дифференцированные ткани) и органной культуре (любой орган, такой как зиготические эмбрионы, корни, побеги). Каждый тип культуры используется в различных направлениях биотехнологии [21].

Генная инженерия растений позволяет манипулировать генетическим материалом и получать конкретные последовательности, кодирующие специфические гены, которые придают определенные характеристики растениям.

После того, как ген изолирован, конструкция готовится встраиваться в соответствующий вектор. Для генетической трансформации используются либо биологическая (Agrobacterium tumefaciens - опосредованная инфекция) или физические методы (обычно бомбардировка микрочастицами). Генетическая трансформация успешно реализуется на таких культурах, как кукуруза, пшеница, хлопок, рис и соя. Среди перечисленных видов растений миллионы гекта- ров земли в настоящее время засажены трансгенными саженцами.

В последнее десятилетие широко используются различные методы редактирования генома, что открывает возможность управления спецефическими, желаемыми мутациями.

Современные научные направления такие как геномика - изучение структуры, функции и регуляции генов, и родственные методы, транскриптомика - изучение транскриптома или набора генов, которые транскрибируются в организме, протеомика - изучение набора белков, транслируемых в организме и метаболомика - изучение всех метаболитов, присутствующих в организме стали ключевыми при изучении биологических процессов в растениях. Знание геномов растений, транскриптомов, протеомы и метаболомы оказали благоприятное влияние на понимание сложных процессов развития, таких как in vitro органогенез, эмбриогенез, или дедифференциация, и генетические изменения, индуцированные в условиях in vitro. Кроме того, метаболомика может быть оченьполезна при исследовании вторичного метаболизма не только в ходе морфогенетических процессов, но главным образом в клеточных, тканевых и органных культурах видов растений, продуцирующих вторичные метаболиты представляющие промышленный и фармацевтический интерес $[20 ; 22 ; 23]$.

В одной из научных работ рассматривались многочисленные эксперименты с дикими популяциями в адаптивной интродукции редкого растения вид Gueldenstaedtia monophylla Fisch. (Fabaceae). Серия введений и дополнений показали некоторый успех. Трансплантаты имели схожую выживаемость и огнестойкость с дикими популяциями, и значительное количество выживших интродуцированных популяций остается более десяти лет. С другой стороны, рост трансплантата в целом был медленным и непоследовательным, а цветение было минимальным [15]. Производство фруктов и сбор рассады второго поколения произошли только в одном не экспериментальном увеличении. Годовая выживаемость широко варьировалась по годам, но была одинаково высокой как правило больше $90 \%$, как для интродуцированных, так и для диких растений. Эта стабильность во 
введенной популяции является сильным показателем того, что реинтродукции и дополнения могут быть успешными в долгосрочной перспективе. Несмотря на высокие ежегодные показатели выживаемости, совокупная выживаемость снижается с каждым годом, и без пополнения (клонального или рассадного) может потребоваться дополнительное увеличение для сохранения размера популяции и генетической структуры $[6 ; 17 ; 27 ; 30]$.

С другой стороны, рост трансплантата был неустойчивым, часто отрицательным, и примерно в десять раз меньше, чем у диких растений. В некоторые годы это изменение в значительной степени объясняется плохим ростом растений, которые вырастали в предыдущем году. Рост варьировался в широких пределах в разные годы и в сложных взаимосвязях с предшествующим этапом истории жизни и происхождением. Изменения в погоде, ирригации, месте пересадки и возрасте растений - все это потенциальные причины, по которым темпы роста варьировались в зависимости от интродукции, проведенной в разные годы. Сильный эффект года также является аргументом для достижения успеха внедрения с многолетним вступлением, как стратегия хеджирования ставок против плохой погоды и других факторов, характерных для отдельных лет [1;25].

При выращивании растений для последующего внесения требуется больше труда и затрат, чем при прямом посеве, при интродукции растений лучше использовать ограниченную доступность семян. Кроме того, трансплантаты крупнее и имеют более высокую выживаемость, чем саженцы, появляющиеся из высаженных семян. Поскольку, по-видимому, требуются десятилетия для того, чтобы даже крупные трансплантаты стали репродуктивно зрелыми, использование семян, которые занимали бы намного больше времени, не кажется хорошей стратегией. Обычно считается, что трансплантаты имеют преимущество перед семенами для многих интродуцированных растений.

Выводы. Метод клонального микроразмножения является достаточно трудоемким и дорогостоящим. Проведение этапов анализируемой технологии требует наличия специализированной оснащенной соответствующим оборудованием лаборатории и наличия высо- коквалифицированного штата сотрудников. Большое внимание уделяется проблеме снижения себестоимости получаемого материала.

В сравнении с традиционными методами размножения растений, несомненно, преимущество имеет применение и использование системы in vitro которая применяется при поддержании коллекций различных видов растений. Среди преимуществ использования данного метода можно выделить такие как: экономия площадей и малые затраты труда специалистов, возможность работы без учета особенностей климата, использование минимального количества эксплантов при получении стерильных культур не нарушая природную популяцию, репродукция материала, трудно размножаемого традиционными методами с возможностью длительного хранения в асептических условиях.

В результате многолетних исследований модифицированы и адаптированы методики клонального микроразмножения редких, ценных и плодово-ягодных растений. При этом, установлено, что реализация морфогенетического потенциала у изученных видов растений определяется видовыми особенностями исходных растений, типом экспланта, его физиологическим состоянием, составом питательных сред и условиями культивирования.

Разведение оздоровленных растений позволяет значительно увеличить выход ценной сельскохозяйственной продукции и высокие адаптационные свойства оздоровленных растений позволяют культивировать их с меньшими затратами химикатов, что значительно увеличивает их пищевую ценность и дает большую возможность получать продукты органического производства.

\section{СПИСОК ЛИТЕРАТУРЫ}

1. Арестова, С. В. Оценка адаптации интродуцированных древесно-кустарниковых растений в условиях Саратовского Поволжья : метод. рекомендации / С. В. Арестова, Е. А. Арестова. - Саратов : НИИСХ Юго-Востока, 2017. - 28 с.

2. Булдаков, С. А. Влияние фунгицида ширлана при клональном микроразмножении картофеля in vitro / С. А. Булдаков, Н. А. Шаклеина, Л. П. Плеханова // Плодоводство и ягодоводство России. - 2015. - Т. 43. - С. 229-232. 
3. Бутенко, Р. Г. Биология клеток высших растений in vitro и биотехнология на их основе / Р. Г. Бутенко. - М. : ФБК-ПРЕСС, 1999. - 160 с.

4. Высоцкий, В. А. Спектральный состав света как регуляторный фактор при клональном микроразмножении ягодных растений / В. А. Высоцкий // Плодоводство и ягодоводство России. - 2016. Т. 44. - С. $126-130$

5. Использование Azospirillum brasilense sp245 для повышения эффективности микроклонального размножения смолевки меловой (Silene cretacea Fisch. ex Spreng.) / Т. А. Крицкая [и др.] // Биотехнология. - 2017. - Т. 33, № 1. - С. 72-79.

6. Клональное микроразмножение и оценка адаптивной способности белоцветковой формы Chamaenerion angustifolium (L.) scop / Д. А. Егорова [и др.] // Вестник Удмурт. ун-та. Сер.: Биология. Науки о Земле. - 2016. - Т. 26, № 4. - С. 25-31.

7. Козьмена, Н. П. Зерноведение с основами биохимии растений: научное издание / Н. П. Козьмена, В. А. Гунькин, Г. М. Суслянок. - М : Колос, 2016. -464 c.

8. Крахмалева, И. Л. Использование клонального микроразмножения для разных форм перспективных сортов Actinidia kolomikta (Rupr. et Maxim) Maxim / И. Л. Крахмалева, О. И. Молканова, Е. В. Малаева // Бюл. Гос. Никит. ботан. сада. - 2019. Вып. 133. - С. 80-86.

9. Малаева, Е. В. Сохранение редких видов растений в коллекции in vitro Волгоградского регионального ботанического сада / Е. В. Малаева // Проблемы ботаники Южной Сибири и Монголии. -2019. - № 18. - С. 606-610.

10. Маркова, М. Г Влияние регуляторов роста на размножение перспективных сортов малины в культуре in vitro / М. Г. Маркова, Е. Н. Сомова, С. А. Потапова // Вестник Дон. гос. аграр. унта. - 2015. - № 2-1 (16). - С. 104-111.

11. Молканова, О. И. Особенности клонального микроразмножения Aristolochia manshuriensis Kom / О. И. Молканова, Д. А. Егорова // Бюл. Глав. ботан. сада. - 2017. - № 1 (203). - С. 58-63.

12. Некоторые аспекты клонального микроразмножения и сохранения in vitro эфиромасличных растений / Н. А. Егорова [и др.] // Тавр. вестник аграр. науки. - 2015. - № 1(3). - С. 18-24.

13. Острикова, О.В.Эффективность клонального микроразмножения сортов и подвойных форм вишни в зависимости от состава питательной среды / О. В. Острикова, А. В. Горбачева, О. Н. Улицкая // Актуальные проблемы естественнонаучного образования, защиты окружающей среды и здоровья человека. - 2016. - Т. 4, № 4. - С. 278-283.

14. Предварительные материалы по реинтродукции Lilium pensylvanicum в окрестностях г. Якутска / Н. С. Данилова [и др.] // Науч. ведомости Белго- род. гос. ун-та. Сер.: Естественные науки. - 2011. № 3. - C. 115-121.

15. Селютина, И. Ю. Изменчивость и межпопуляционная дифференциация редкого вида Gueldenstaedtia monophylla Fisch. (Fabaceae), выявляемая методом SDS-электрофореза / И. Ю. Селютина, Е. С. Кониченко, О. В. Дорогина // Вавиловский журнал генетики и селекции. - 2017. - Т. 2, № 3. - С. 354-359.

16. Тимофеева, С. Н. Гистологические аспекты клонального микроразмножения Laburnum anagyroides Medic / С. Н. Тимофеева, О. И. Юдакова, А. И. Степанова // Бюл. Гос. Никит. ботан. сада. 2016. - № 120. - С. 30-35.

17. Шевченко, И. В. Реинтродукция редких и сокращающих численность в белгородской области видов Iris L в ботаническом саду Белгородского университета / И. В. Шевченко, В. И. Чернявских, О. А. Сороконудова // Науч. ведомости Белгород. гос. ун-та. Сер.: Естественные науки. - 2011. - № 9 (104).C. 88-92.

18. Шипунова, А. А. Влияние некоторых факторов культивирования на клональное микроразмножение плодовых и ягодных растений / А. А. Шипунова, В. А. Высоцкий // Плодоводство и ягодоводство России. - 2012. - Т. 9. - С. 193-200.

19. Якимова, О. В. Влияние состава питательной среды и генотипа на клональное микроразмножение душицы in vitro / О. В. Якимова, Н. А. Егорова // Труды Кубан. гос. аграр. ун-та. 2015. - № 55. - C. 304-309.

20. Belmonte, M. F. Alterations of the Glutathione Redox State Improve Apical Meristem Structure and Somatic Embryo Quality in White Spruce (Picea glauca)/ M. F. Belmonte, G. Donald, D. M. Reid // J. Exp. Bot. - 2005. - № 56. - P. 2355-2364.

21. Bonga, J. M. Recalcitrance in Clonal Propagation, in Particular of Conifers / J. M. Bonga, K. K. Klimaszewska, P. von Aderkas // Plant. Cell Tiss. Organ. Cult. - 2010. - Vol. 100. - P. 241-254.

22. Chen, J. Ornamental Foliage Plants: Improvement Through Biotechnology / J. Chen, R. J. Henny ; A. and S.K. Sopory (eds.) // Recent Advances in Plant Biotechnology and Its Application. - New Delhi : I. K. International Publishing House Pvt. Ltd., 2008. P. $140-156$.

23. Clouse, S. Plant Development: a Role for Sterols in Embryogenesis / S. Clouse // Curr Biol. 2010. - № 10. - P. 601-604.

24. Lai, R. Role of Tissue Culture in Rapid Clonal Propagation and Production of Pathogen-Free Plants / R. Lai, S. Lai // Crop Improvement Utilizing Biotechnology. -2019. - P. 73-116.

25. Lee, J. E. Determination of Chokeberry (Aronia melanocarpa) Polyphenol Components Using Liquid Chromatography-Tandem Mass 
Spectrometry: Overall Contribution to Antioxidant Activity/ J. E. Lee, G. S. Kim, S. Park // Food Chem. 2014. - Vol. 146. - P. 1-5.

26. Microclonal Propagation of Plant Process Modeling and Optimization of its Parameters Based on Neural Network/O.A. Ivashchuk [et al.]// Drug Invention Today. - 2018. - Vol. 10, Sp. iss. 3. - P. 3127-3175.

27. Mozafari, A. A. In Vitro Propagation and Conservation of Satureja Avromanica Maroofi - an Indigenous Threatened Medicinal Plant of Iran / A. A. Mozafari, Y. Vafaee, E. Karami // Physiology and Molecular Biology of Plants. - 2015. - Vol. 21, № 3. - P. 433-439.

28. Plant Micropropagation In Desert Rehabilitation - a Success Story / C. Sudhersan, S. Jibi, L. Al-Sabah [et al.] // In Vitro Cell Dev. Biol. Anim. 2015. - Vol. 51, P. 34-35.

29. Singh, A. Micropropagation of Plants // Plant Biology and Biotechnology / B. Bahadur [et al.]. New Delhi : Springer, 2015. - P. 329-346.

30. Smith, S. A. Adaptive Introductions: How Multiple Experiments and Comparisons to Wild Populations Provide Insights into Requirements for Long-Term Introduction Success of an Endangered Shrub / S. A. Smith, C. W. Weekley // Plant Divers. 2016. - Vol. 38, № 5. - P. 238-246.

\section{REFERENCES}

1. Arestova S.V. Otsenka adaptatsii introdutsirovannykh drevesno-kustarnikovykh rastenij v uslovijakh Saratovskogo Povolzhja: metodicheskie rekomendatsii. Saratov NIISH JugoVostoka, 2017, 28 p.

2. Buldakov S.A., Shakleina N.A., Plehanova L.P. Vliyanie fungicida Shirlana pri klonal'nom mikrorazmnozhenii kartofelya in vitro [Influence of Fungicide Shirlan During the Clonal Micropropagation of Potato in Vitro] Plodovodstvo i Yagodovodstvo Rossii [Pomiculture and Small Fruits Culture in Russia], 2015, vol. 43, pp. 229-232.

3. Butenko R.G. Biologiya kletok vysshikh rastenij in vitro $i$ biotehnologiya na ikh osnove [Biology of Higher Plants in vitro and Biotechnology and biotechnology based on them], Msk FBK-PRESS, $1999,160 \mathrm{p}$.

4. Vysockij V.A. Spektral'nyj sostav sveta kak regulyatornyj faktor pri klonal'nom mikrorazmnozhenii yagodnykh rastenij [Light spectral composition as a regulator during clonal micropropagation of small fruit plants]. Plodovodstvo $i$ Yagodovodstvo Rossii [Pomiculture and Small Fruits Culture in Russia], 2016, vol. 44, pp. 126-130.

5. Kritskaya T.A., Evseeva N.V., Burygin G.L., et al. Ispolzovanie Azospirillum brasilense sp245 dlya povysheniya effektivnosti mikroklonal'nogo razmnozheniya Silene cretacea Fisch. ex Spreng [Use of Azospirillum brasilense Sp245 to Increase the Efficacy of Clonal Micropropagation of Cretaceous Catchfly (Silene cretacea Fisch. ex Spreng.). Biotekhnologiya - Biotechnology in Russia, 2017, vol. 33, no.1, pp. 72-79. DOI: https://doi.org/ 10.21519/0234-2758-2017-33-1-72-79.

6. Egorova D.A., Vinogradova Yu.K., Gorbunov Ju.N., Molkanova O.I. Klonalnoe mikrorazmnozhenie i otsenka adaptivnoj sposobnosti belotsvetkovoj formy Chamaenerion angustifolium (L.) scop [Micropropagation of the albiflorous form Chamaenerion angustifolium (L.) Scop. and evaluation of its adaptive ability]. Vestnik Udmurtskogo universiteta. Serija Biologiya. Nauki o Zemle [Bulletin of Udmurt University. Series Biology. Earth Sciences], 2016, vol. 26, no. 4, pp. 25-31.

7. Kozmena N.P. Zernovedenie s Osnovami Biokhimii Rastenij [Grain Science with Basics of Plant Biochemistry]. Moscow, Kolos, 2016. 464 p.

8. Krakhmaleva I.L., Molkanova O.I., Malaeva E.V. Ispolzovanie klonalnogo mikrorazmnozheniya dlya raznykh form perspektivnykh sortov Actinidia kolomikta (Rupr. et Maxim) Maxim [Features of Clonal Micropropagation of Different Forms in Promising Cultivars of Actinidia kolomikta (Rupr. Et Maxim) Maxim]. Byulleten Gosudarstvennogo Nikitskogo botanicheskogo sada [Bulletin of the State Nikitsky Botanical Garden], 2019, iss. 133, pp. 80-86. DOI: https:/ /doi.org/10.36305/05131634-2019-133-80-86.

9. Malaeva E.V. Sokhranenie redkikh vidov rastenij $\mathrm{v}$ kollektsii in vitro Volgogradskogo regionalnogo botanicheskogo sada [Conservation of Rare Plant Species in Vitro Collection of Volgograd Regional Botanical Garden]. Problemy Botaniki Juzhnoj Sibiri i Mongolii [Problems of Botany of South Siberia and Mongolia], 2019, vol. 1, no. 18, pp. 606-610. DOI: https://doi.org/10.14258/pbssm.2019127.

10. Markova M.G., Somova E.N., Potapova S.A. Vliyanie regulyatorov rosta na razmnozhenie perspektivnykh sortov maliny v kulture in vitro [Influence of Growth Regulators the Reproduction of Promising Varieties of Raspberries in Culture in Vitro]. Vestnik Donskogo Gosudarstvennogo Agrarnogo Universiteta [Vestnik of Don State Agrarian University], 2015, № 2-1 (16), pp. 104-111.

11. Molkanova O.I., Egorova D.A. Osobennosti klonalnogo mikrorazmnozheniya Aristolochia manshuriensis Kom [Clonal Micropropagation of Aristolochia Manshuriensis Kom] Byulleten Glavnogo Botanicheskogo Sada [Bulletin of the Central Botanical Garden, 2017, no. 1 (203), pp. 58-63.

12. Egorova N.A., Stavtseva I.V., Jakimova O.V., et al. Nekotorye aspekty klonalnogo mikrorazmnozhenija i sokhranenija in vitro jefiromaslichnykh rastenij [Some Aspects of Clonal Micropropagation and in Vitro 
Conservation of Essential Oil Plants]. Tavricheskij vestnik agrarnoj nauki [Tauride Bulletin of Agricultural Science], 2015, no. 1 (3), pp. 18-24.

13. Ostrikova O.V., Gorbacheva A.V., Ulickaja O.N. Effektivnost klonalnogo mikrorazmnozheniya sortov $\mathrm{i}$ podvojnykh form vishni $\mathrm{v}$ zavisimosti ot sostava pitatel'noj sredy [Efficiency of Clonal Micropropagation of Cherry Varieties and Rootstock forms Depending on the Composition of the Nutrient Medium]. Aktualnye Problemy Estestvennonauchnogo Obrazovaniya, Zashhity Okruzhayushchej Sredy i Zdorovya Cheloveka [Actual Problems of Science Education, Environment Protection and Human Health], 2016, vol. 4, no. 4, pp. 278-283.

14. Danilova N.S., Ivanova N.S., Borisova S.Z., Afanasyeva E.A. Predvaritelnye materialy po reintroduktsii Lilium pensylvanicum $\mathrm{v}$ okrestnostyakh g. Jakutska [Preliminary Materials on the Reintroduction of Lilium Pensylvanicum in the Vicinity of Yakutsk]. Nauchnye Vedomosti Belgorodskogo Gosudarstvennogo Universiteta. Seriya: Estestvennye nauki [Scientific Bulletins of the Belgorod State University. Series: Natural Sciences], 2011, no. (98), pp. 115-121.

15. Selyutina I.Yu., Konichenko E.S., Dorogina O.V. Izmenchivost i mezhpopulyacionnaya differenciatsiya redkogo vida Gueldenstaedtia monophylla Fisch. (Fabaceae), vyyavlyaemaya metodom SDS-elektroforeza [Variability and Interpopulation Differentiation of the Rare Species Gueldenstaedtia Monophylla Fisch. (Fabaceae) Using SDS-Electroforesis]. Vavilovskij Zhurn. Genetiki $i$ Selekcii [Vavilov Journal of Genetics and Breeding], 2017, vol. 2, no. 3, pp. 354-359. DOI: https://doi.org/ 10.18699/18699/VJ16.15-o.

16. Timofeeva S.N., Judakova O.I, Stepanova A.I. Gistologicheskie aspekty klonalnogo mikrorazmnozheniya Laburnumana gyroides Medic [Histological Aspects of Clonal Micro-Propagation of Laburnumana gyroides Medic]. Byulleten Gosudarstvennogo Nikitskogo botanicheskogo sada [Bulletin of the State Nikitsky Botanical Garden], 2016, no. 120 , pp. $30-35$.

17. Shevchenko I.V., Chernjavskih V.I., Sorokonudova O.A. Reintrodukcija redkih i sokrashhajushhih chislennost $\mathrm{v}$ belgorodskoj oblasti vidov Iris L v botanicheskom sadu Belgorodskogo universiteta [Reintroduction of Rare and Reduced Iris L Species in the Belgorod Region on the Base on Botanical Garden of the Belgorod University] Nauchnye Vedomosti Belgorodskogo Gosudarstvennogo Universiteta. Seriya: Estestvennye nauki [Scientific Bulletins of the Belgorod State University. Series: Natural Sciences], 2011, no. 9 (104), pp. 88-92.

18. Shipunova A.A., Vysockij V.A. Vliyanie nekotorykh faktorov kultivirovaniya na klonalnoe mikrorazmnozhenie plodovykh i jagodnykh rastenij [Influence of Some Cultural Factors on Micropropagation of Fruit Trees and Small Fruits]. Plodovodstvo $i$ Yagodovodstvo Rossii [Pomiculture and Small Fruits Culture in Russia], 2012, vol. 9, pp.193-200.

19. Yakimova O.V., Egorova N.A. Vliyanie sostava pitatelnoj sredy i genotipa na klonalnoe mikrorazmnozhenie dushitsy in vitro [The Influence of the Composition of the Nutrient Medium and Genotype on Clonal Micropropagation of Origanum in Vitro]. Trudy Kubanskogo Gosudarstvennogo Agrarnogo Universiteta [Proceedings of the Kuban State Agrarian University], 2015, no. 55, pp. 304-309.

20. Belmonte M.F., Donald G., Reid D.M., et al. Alterations of the Glutathione Redox State Improve Apical Meristem Structure and Somatic Embryo Quality in White Spruce (Piceaglauca). J. Exp. Bot., 2005, vol. 56, pp. 2355-2364.

21. Bonga J.M., Klimaszewska K.K., von Aderkas P. Recalcitrance in Clonal Propagation, in Particular of Conifers. Plant. Cell Tiss. Organ. Cult., 2010, vol. 100, pp. 241-254.

22. Chen J., Henny R.J. Ornamental Foliage Plants: Improvement Through Biotechnology. Recent Advances in Plant Bio-technology and Its Application. New Delhi, I.K. International Publishing House Pvt. Ltd., 2008, pp. 140-156.

23. Clouse S. Plant Development: a Role for Sterols in Embryogenesis. Curr. Biol., 2010, vol. 10, pp. 601-604.

24. Lai R., Lai S. Role of Tissue Culture in Rapid Clonal Propagation and Production of Pathogen-Free Plants. Crop Improvement Utilizing Biotechnology, 2019,pp. 73-116.

25. Lee J.E., Kim G.S., Park S., et al. Determination of Chokeberry (Aronia melanocarpa) Polyphenol Components Using Liquid Chromatography-Tandem Mass Spectrometry: Overall Contribution to Antioxidant Activity. Food Chem, 2014, vol. 146, pp. 1-5.

26. Ivashchuk O.A., Fedorov V.I., Shcherbinina N.V., et al. Microclonal Propagation of Plant Process Modeling and Optimization of its Parameters Based on Neural Network. Drug Invention Today, 2018, vol. 10, sp. iss. 3, pp. 3127-3175.

27. Mozafari, A. A., Vafaee, Y., Karami, E. In Vitro Propagation and Conservation of Satureja Avromanica Maroofi - an Indigenous Threatened Medicinal Plant of Iran. Physiology and Molecular Biology of Plants, 2015, vol. 21 (3), pp. 433-439.

28. Sudhersan C., Jibi S., Al-sabah L., et al. Plant Micropropagation in Desert Rehabilitation - a Success story. In Vitro Cell Dev. Biol. Anim, 2015, vol. 51, pp. 34-35.

29. Singh, A. Micropropagation of Plants. Plant Biology and Biotechnology. New Delhi : Springer, 2015, pp. 329-346. 
30. Smith S.A., Weekley C.W. Adaptive Introductions: How Multiple Experiments and Comparisons to Wild Populations Provide Insights
Into Requirements for Long-Term Introduction Success of an Endangered Shrub. Plant Divers, 2016, vol. 38, no. 5, pp. 238-246.

\section{Information About the Authors}

Victoria O. Samarskaya, Student, Department of Bioengineering and Bioinformatics, Volgograd State University, Prosp. Universitetsky, 100, 400062 Volgograd, Russian Federation, Viktoria.samarskaya2012@yandex.ru.

Elena V. Malaeva, Candidate of Sciences (Biology), Deputy Director for Science, Volgograd Regional Botanical Garden, Metallurgov Village, 68, 400007 Volgograd, Russian Federation; Associate Professor, Department of Theory and Methods of Biological and Chemical Education and Landscape Architecture, Volgograd State Social and Pedagogical University, Prosp. V.I. Lenina, 27, 400066 Volgograd, Russian Federation, e.malaeva@mail.ru.

Margarita V. Postnova, Doctor of Sciences (Biology), Senior Researcher, Head of the Department of Bioengineering and Bioinformatics, Volgograd State University, Prosp. Universitetsky, 100, 400062 Volgograd, Russian Federation, postnova@volsu.ru.

\section{Информация об авторах}

Виктория Олеговна Самарская, студент кафедры биоинженерии и биоинформатики, Волгоградский государственный университет, просп. Университетский, 100, 400062 г. Волгоград, Российская Федерация, Viktoria.samarskaya2012@yandex.ru.

Елена Викторовна Малаева, кандидат биологических наук, заместитель директора по науке, Волгоградский региональный ботанический сад, пос. Металлургов, 68, 400007 г. Волгоград, Российская Федерация; доцент кафедры теории и методики биолого-химического образования и ландшафтной архитектуры, Волгоградский государственный социально-педагогический университет, просп. им. В.И. Ленина, 27, 400066 г. Волгоград, Российская Федерация, e.malaeva@mail.ru.

Маргарита Викторовна Постнова, доктор биологических наук,старший научный сотрудник, заведующая кафедры биоинженерии и биоинформатики, Волгоградский государственный университет, просп. Университетский, 100, 400062 г. Волгоград, Российская Федерация, postnova@volsu.ru. 